\title{
Liquid- Liquid Extraction of Zinc(II) From Acid Media with N-n-Heptylaniline as an Extractant: Analysis of Pharmaceutical and Commercial Sample
}

\author{
Pawar RR ${ }^{1}$, Suryavanshi VJ ${ }^{1}$, Patil MM${ }^{1}$, Patil SS $^{2}$ and Mulik GN*1 \\ ${ }^{1}$ Department of Chemistry, Balwant College, Vita-415311, India
}

${ }^{2}$ Department of Chemistry, PDVP College, Tasgaon-416312, India

Received: 筒: October 10, 2018; Published: 眥: October 29, 2018

*Corresponding author: Mulik GN, PG, Department of Chemistry, Balwant College, Vita-415 311, India

\begin{abstract}
The extraction of zinc(II) from acid media by N-n-heptylaniline in xylene has been studied for metal distribution measurements. Various physicochemical parameters like acid concentration, reagent concentration, equilibrium time, effect of diluents, aqueous to organic phase ratio, stripping agents and loading capacity were investigated for the quantitative extraction. The extraction was carried out from $3 \mathrm{M}$ hydrochloric acid and $0.5 \mathrm{M} \mathrm{N}$-n-heptylaniline concentration. Zinc(II) was selectively extracted and separated from many metal ions and synthetic mixtures. The nature of the extracted species was determined. Zinc(II) was analyzed from pharmaceutical samples and nycil talk powder.
\end{abstract}

Keywords: Zinc(II); Liquid Liquid Extraction; Acid Media; N-n-Heptylaniline; Pharmaceutical Samples; Nycil Talk Powder

\section{Introduction}

The uses of zinc(II) are in the production of die-casting alloys, in galvanizing industry, pharmaceutical samples, in the manufacture of brass products, rolled zinc(II) products of various types, light metal alloys, in desilvering lead and in wet-batteries. It is starting material for the production of zinc(II) oxide. Zinc(II) is an essential trace element in plant and animal life. The zinc(II) content in humans is $2-4 \mathrm{~g}$ [1]. Zinc(II) is also essential constituent of several enzymes necessary for metabolism. It is necessary to develop the simple, rapid and selective method of separation for zinc(II) from different elements. For extraction and separation of zinc(II) solvent extraction is useful method. Solvent extraction of zinc(II), indium(III), thallium(III) and bismuth(III) with n-octylaniline from hydrochloric acid media and their separation carried out [2].

The distribution equilibrium of zinc(II) between synergistic mixture of $\mathrm{N}$-n-octylaniline and trioctylamine in xylene from thiocyanate media has been investigated [3]. The solvent extraction of zinc(II) from thiocyanate and sulphuric acid media using N-nhexylaniline in xylene is described [4]. Solvent extraction of zinc from strong hydrochloric acid solution with alamine 336 has been carried out [5]. Liquid-liquid extraction of zinc(II) by 3-methylquinoxaline-2-thione from nitrate medium investigated [6]. Separation of iron and zinc(II) from manganese nodule leach liquor using TBP as extractant is studied [7]. Solvent extraction utilized for the selective separation of zinc(II) from other elements in hydrometallurgical processing of resources [8]. Zinc(II) chloride and hydrochloric acid extraction from solutions of high zinc(II) concentration by tri-n-butyl phosphate diluted in ShellSol2046 (an aliphatic solvent) has been studied with a combination of experiments and mathematical Modeling [9]. From chloride solutions solvent extraction of zinc(II) carried out [10].

The mean centering of ratio kinetic profiles method was used for the simultaneous determination of binary mixtures of $\mathrm{Ni}(\mathrm{II})$ and $\mathrm{Zn}(\mathrm{II})$ in water samples, without prior separation steps [11]. Synergistic extraction of zinc(II) by mixtures of primary amine N1923 and cyanex 272 investigated [12]. The solvent extraction of zinc(II), cadmium(II) and chromium(III) from phosphoric acid solutions by tri-n-butyl phosphate in kerosene as diluent was investigated [13]. The extraction and separation of zinc(II), manganese(II), cobalt(II) and nickel(II) from nickel laterite bacteria leach liquor were carried out using sodium salts of TOPS-99 and Cyanex 272 in kerosene [14]. The selective removal of zinc(II) over iron (II) by liquid-liquid extraction from spent hydrochloric acid pickling effluents produced by the zinc(II) hot-dip galvanizing industry was studied at room temperature [15]. Extraction and separation of cobalt(II) and zinc(II) was studied from a sulphate solution using NaD2EHPA, NaPC88A and NaCyanex 271 of $0.04 \mathrm{M}$ concentration [16]. The liquid-liquid extraction of zinc(II) using D2EHPA as extractant has been investigated in order to recover 
zinc(II)sulphate from an industrial effluent produced by Votorantim Co. which contains several metallic species such as cadmium, cobalt, iron, lead, calcium, magnesium, manganese and nickel [17].

The extraction of zinc(II) and cadmium(II) with mixtures of neutral organophosphorus extractants and amine extractants has been investigated [18]. Synergistic solvent extraction and transport of $\mathrm{Zn}(\mathrm{II})$ and $\mathrm{Cu}(\mathrm{II})$ across polymer inclusion membranes with a mixture of TOPO and aliquat 336 carried out [19]. Extraction of $\mathrm{Zn}$ (II) from aqueous hydrochloric acid solutions into alamine-336 m-xylene systems was studied [20]. 3-hydroxybenzylaminobenzoic acid synthesized as a reagent for the determination of zinc(II) in various water samples [21]. Recovery of both sulphuric acid and zinc(II) bleed stream generated during the electrowinning of zinc(II) in the zinc(II) refineries using tris-(2-ethylhexyl) amine dissolved in kerosene has been investigated in detail [22]. The extraction of Zn(II), Fe(II), Fe(III) and Cd(II) with Tributylphosphate (TBP) and commercial trioctyl phosphine oxide in kerosene from chloride medium has been studied [23]. Solvent extraction behavior of zinc(II), cadmium(II), mercury(II) and bismuth(III) with n-octylaniline in different organic solvents from various aqueous acid solutions has been investigated [24].

An accurate, inexpensive and less laborious liquid-liquid extractive spectrophotometric procedure for the determination of zinc(II) in aqueous media has been developed [25]. Previously we have reported number of solvent extraction methods for the quantitative extraction of platinum group metals with amines [2639]. In present research paper a systematic study of extraction of zinc(II) with N-n-heptylaniline in xylene has been carried out. The extracted complex species in the organic phase zinc(II) was back extracted with $0.5 \mathrm{M}$ ammonia solution $(2 \mathrm{X} 10 \mathrm{~mL})$ and was determined complexometrically. Various parameters such as acid-reagent concentration, equilibrium period, effect of various diluents, enrichment study, loading capacity and diverse ions were also studied. The study was also extended for analysis of synthetic mixtures and pharmaceutical sample.

\section{Experimental}

\section{Apparatus}

Mettler toledo model-ML204 electronic balance with accuracy $0.0001 \mathrm{~g}$ was used for weighing. For $\mathrm{pH}$ measurement Elico digital pH meter model LI-120 with combined glass electrode was used. All glass wares were cleaned by acidified solution of potassium dichromate and finally rinsed with water.

\section{Reagents}

\section{Standard Zinc(II) Sulphate Solution (1 mg/mL)}

The stock solution of Zinc(II) was prepared by dissolving $5.49 \mathrm{~g}$ of Zinc(II) sulphate $\left(\mathrm{ZnSO}_{4} \cdot 7 \mathrm{H}_{2} \mathrm{O}\right)$ in $250 \mathrm{~mL}$ of distilled water containing $0.5 \mathrm{~mL}$ of concentrated sulphuric acid. The solution was standardized and diluted as required for working purpose.

\section{Ethylene Diaminetetraacetic Acid Solution (0.001M)}

A solution of ethylene diaminetetraacetic acid $(0.01 \mathrm{M})$ was prepared by dissolving 3.722g EDTA in distilled water and diluting to $1000 \mathrm{~mL}$ and standardized complexometrically. Working solution of EDTA $(0.001 \mathrm{M})$ was prepared by proper dilution.

\section{Buffer Solution $\left(\mathrm{P}^{\mathrm{H}}\right.$ 10)}

A pH 10 buffer solution was prepared by adding $142 \mathrm{~mL}$ concentrated ammonia solution (sp.gr. 0.88-0.90) to $17.5 \mathrm{~g}$ ammonium chloride and dilute it to $250 \mathrm{~mL}$ with distilled water.

\section{N-n-Heptylaniline Solution (0.5M)}

N-n-heptylaniline was synthesized by the method of Z. G. Gardlund [40] and its solution (\%,v/v) was prepared by using xylene as the diluent.

\section{General Procedure}

To an aliquot of solution containing $1 \mathrm{mg}$ of zinc(II), add sufficient quantity of hydrochloric acid to make the concentration of $3 \mathrm{M}$ in a total volume of $10 \mathrm{~mL}$. Transfer the solution into a $125 \mathrm{~mL}$ separating funnel and shake the solution for 1 minute with $10 \mathrm{~mL}$ of $0.5 \mathrm{M} \mathrm{N}$-n-heptylaniline. The swirl the solution and allow to separate the two phases. After phase separation, strip the zinc(II) from organic phase with two $20 \mathrm{~mL}$ portions of $0.5 \mathrm{M}$ ammonia solution. Collect and combine the aqueous extract and estimate zinc(II) complexometrically [41].

\section{Results and Discussion}

\section{Influence of Acid Concentration on Extraction of Zinc(II)}

The extraction of $1 \mathrm{mg}$ of zinc(II) was studied from hydrochloric, hydrobromic, hydroiodic, sulphuric, nitric and perchloric acid media in the range of 0.1 to $8.0 \mathrm{M}$ with $0.5 \mathrm{M} \mathrm{N}$-n-heptylaniline in xylene keeping the aqueous to organic volume ratio $1: 1$. The extraction of zinc(II) increases with increase in acid concentration and becomes quantitative in 2.0 to $4.0 \mathrm{M}$ hydrochloric, hydrobromic and hydroiodic acid. While zinc(II) was not extracted with remaining acids. Upon further increase in hydrochloric, hydrobromic and hydroiodic acid concentration the extraction of zinc(II) decreases (Figure 1), 3.0 M concentration of hydrochloric acid was used throughout the work, as it has a wide range of applications as compared with hydrobromic and hydroiodic acid.

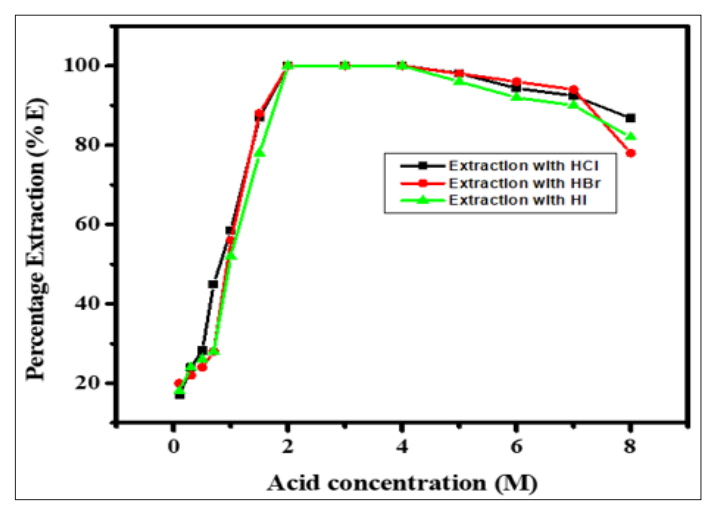

Figure 1: Extraction behaviour of $\mathrm{Zn}(\mathrm{II})$ as a function of hydrochloric, hydrobromic and hydroiodic acid concentration, Conditions: $\mathrm{Zn}(\mathrm{II})=1 \mathrm{mg}$, N-n-heptylaniline $=0.5 \mathrm{M}$ in xylene, aq.: org. ratio $=1: 1$, shaking time $=1 \mathrm{~min}$, strippant $=$ ammonia buffer $(2 \times 10 \mathrm{~mL})$. 


\section{Influence of Extractant Concentration on Extraction of Zinc(II)}

The effect of extractant concentration was scanned for the range of $0.03 \mathrm{M}$ to $0.6 \mathrm{M}$ of $\mathrm{N}$-n-heptylaniline on the $1 \mathrm{mg}$ zinc(II) from $3 \mathrm{M}$ hydrochloric acid. Increase in $\mathrm{N}$-n-heptylaniline concentration was found to be increase the extraction of zinc(II). The excess of reagent concentration had no adverse effect on magnitude of extraction (Figure 2). It was found that, $10 \mathrm{~mL}$ of $0.5 \mathrm{M} \mathrm{N}$-n-heptylaniline was sufficient for the quantitative extraction of $1.0 \mathrm{mg}$ of zinc(II) from 3.0 M hydrochloric acid. Therefore, in the recommended procedure $0.5 \mathrm{M}$ N-n-heptylaniline in xylene has to be used to ensure complete extraction of zinc(II).

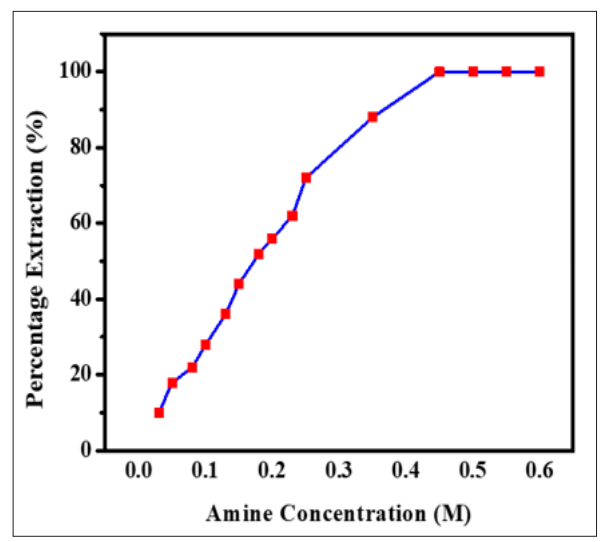

Figure 2: Influence of amine concentration on extraction of Zinc(II), Conditions: $\mathrm{Zn}(\mathrm{II})=1 \mathrm{mg}, \mathrm{HCl}=3.0 \mathrm{M}$, aq.: org. ratio $=1: 1$, shaking time $=1 \mathrm{~min}$, strippant $=$ ammonia buffer $(2 \times 10 \mathrm{~mL})$.

Influence of Contact Time on Extraction of Zinc(II) The effect of phase contact time on the distribution ratio for the extraction of zinc(II) from $3 \mathrm{M}$ hydrochloric acid using $0.5 \mathrm{M} \mathrm{N}-\mathrm{n}$ heptylaniline in xylene has been studied (Table 1). Variation of shaking time from $10 \mathrm{~s}$ to $20 \mathrm{~min}$ showed that a minimum of $30 \mathrm{~s}$ shaking is needed for the complete extraction of zinc(II). The prolonged shaking had no adverse effect on the extraction, hence $1 \mathrm{~min}$ shaking is recommended in the general procedure to ensure the quantitative extraction of zinc(II).

Table 1: Effect of equilibration time.

\begin{tabular}{|c|c|c|}
\hline $\begin{array}{c}\text { Equilibration time } \\
\text { (min) }\end{array}$ & $\begin{array}{c}\text { Percentage } \\
\text { extraction,(\% E) }\end{array}$ & $\begin{array}{c}\text { Distribution ratio, } \\
\text { (D) }\end{array}$ \\
\hline 0.08 & 96 & 36 \\
\hline 0.17 & 98 & 49 \\
\hline 0.25 & 100 & $\infty$ \\
\hline 0.50 & 100 & $\infty$ \\
\hline 0.75 & 100 & $\infty$ \\
\hline $1^{*}$ & 100 & $\infty$ \\
\hline 1.5 & 100 & $\infty$ \\
\hline 2 & 100 & $\infty$ \\
\hline 3 & 100 & $\infty$ \\
\hline 4 & 100 & $\infty$ \\
\hline
\end{tabular}

\begin{tabular}{|c|l|l|}
\hline 5 & 100 & $\infty$ \\
\hline 7 & 100 & $\infty$ \\
\hline 10 & 100 & $\infty$ \\
\hline 15 & 100 & $\infty$ \\
\hline 20 & 100 & $\infty$ \\
\hline 30 & 100 & $\infty$ \\
\hline
\end{tabular}

Note: *Recommended for general extraction procedure

Conditions: $\mathrm{Zn}(\mathrm{II})=1 \mathrm{mg}, \mathrm{N}-\mathrm{n}$-heptylaniline $=0.5 \mathrm{M}$ in xylene, $\mathrm{HCl}=3.0 \mathrm{M}$, aq.: organic ratio $=1: 1$, strippant $=$ ammonia buffer $(2 \times 10 \mathrm{~mL})$.

\section{Extraction with Various Diluents}

According to Sole appropriate hydrocarbon mixture used as diluents, having flash and boiling point above $60^{\circ} \mathrm{C}$ and density of $0.8 \mathrm{~g} / \mathrm{cm}^{-3}$ to aid phase separation. The extractability and selectivity for the extraction of metal ions by organic extractant are greatly affected by the nature of solvent. A number of different diluents were tested for the extraction of zinc(II). To discern the effect of nature of various aromatic and aliphatic diluents on the extraction of zinc(II) the organic diluents namely xylene, toluene, benzene, nitrobenzene, carbon tetrachloride and chloroform (Table 2). Out of these diluents, zinc(II) was quantitatively extracted in the xylene, toluene, benzene and nitrobenzene while the remaining solvents give incomplete extraction of zinc(II). Among this xylene was preferred as a diluent for further studies since it provide better phase separation, relatively lower aqueous solubility, ready availability and relative low cost.

Table 2: Effect of diluents.

\begin{tabular}{|c|c|c|c|}
\hline Diluents & $\begin{array}{c}\text { Dielectric } \\
\text { constant, ( } \boldsymbol{\epsilon} \text { ) }\end{array}$ & $\begin{array}{c}\text { Percentage } \\
\text { Extraction, (\% } \\
\text { E) }\end{array}$ & $\begin{array}{c}\text { Distribution ratio, } \\
\text { (D)b }\end{array}$ \\
\hline Xylene* & 2.30 & 100 & $\infty$ \\
\hline Benzene & 2.28 & 100 & $\infty$ \\
\hline Toluene & 2.38 & 100 & $\infty$ \\
\hline Nitrobenzene & 34.8 & 100 & $\mathbf{5 . 3 7}$ \\
\hline $\begin{array}{c}\text { Carbon- } \\
\text { tetrachloride }\end{array}$ & 2.24 & 84.3 & $\mathbf{0 . 3 8}$ \\
\hline Chloroform & 4.81 & 27.5 & \\
\hline
\end{tabular}

Note: *Recommended for general extraction procedure

Conditions: $\mathrm{Zn}(\mathrm{II})=1 \mathrm{mg}$, N-n-heptylaniline $=0.5 \mathrm{M}$ in xylene, $\mathrm{HCl}$ $=3.0 \mathrm{M}$, aq.: organic ratio $=1: 1$, Shaking time $=1 \mathrm{~min}$, strippant $=$ ammonia buffer $(2 \times 10 \mathrm{~mL})$.

\section{Effect of Aqueous to Organic Volume Ratio}

To find out whether large aqueous: organic volume ratio could be tolerated for the successfully extraction of zinc(II) by N-nheptylaniline under optimum condition. Zinc(II) was extracted from aqueous (10 to $150 \mathrm{~mL}$ ) of $3.0 \mathrm{M} \mathrm{HCl}$ with $10 \mathrm{~mL}$ of $0.5 \mathrm{M} \mathrm{N}$-nheptylaniline in xylene. Zinc(II) was stripped and determined as described in the general procedure. It was found that extraction of zinc(II) was quantitative when aqueous to organic volume ratio was only 1:1 and it decreased beyond it this may be attribute to the less stability of ion pair formed under conditions (Table 3). 
Table 3: Effect of aqueous to organic phase ratio.

\begin{tabular}{|c|c|c|}
\hline $\begin{array}{c}\text { Aqueous to organic } \\
\text { phase ratio }\end{array}$ & $\begin{array}{c}\text { Percentage } \\
\text { Extraction, (\% E) }\end{array}$ & $\begin{array}{c}\text { Distribution ratio, } \\
\text { (D) }\end{array}$ \\
\hline $10: 10^{*}$ & 100 & $\infty$ \\
\hline $15: 10$ & 96.1 & 24.6 \\
\hline $20: 10$ & 84.3 & 5.37 \\
\hline $30: 10$ & 52.9 & 1.12 \\
\hline $40: 10$ & 15.7 & 0.19 \\
\hline $50: 10$ & 9.80 & 0.11 \\
\hline $100: 10$ & 5.88 & 0.06 \\
\hline $150: 10$ & 0.00 & - \\
\hline
\end{tabular}

Note: *Recommended for general extraction procedure

Conditions: $\mathrm{Zn}(\mathrm{II})=1 \mathrm{mg}, \mathrm{N}$-n-heptylaniline $=0.5 \mathrm{M}$ in xylene, $\mathrm{HCl}=3.0 \mathrm{M}$, Shaking time $=1 \mathrm{~min}$, strippant $=$ ammonia buffer $(2 \times 10 \mathrm{~mL})$.

\section{Influence of Loading Capacity of N-n-Heptylaniline}

The loading capacity of N-n-heptylaniline in xylene was studied by equilibrating zinc(II) in $3 \mathrm{M}$ hydrochloric acid at fixed aqueous to organic ratio (1:1) for $1 \mathrm{~min}$. The two phases were separated, and the same organic phase was again used for the extraction of fresh zinc(II). The extraction of zinc(II) by same $\mathrm{N}$-n-heptylaniline was repeated till no further extraction of zinc(II) was observed in the organic phase. In the saturated organic phase of $\mathrm{N}$-n-heptylaniline the amount of zinc(II) was found to be $5 \mathrm{mg}$.

\section{Nature of the Extracted Species}

Stoichiometry of the extracted species was determined by plotting $\log \mathrm{D}_{[\mathrm{Zn}(\mathrm{II})]}$ versus $\log \mathrm{C}_{[\mathrm{HCl}]}$ at 0.05 and $0.25 \mathrm{M} \mathrm{N}$-nheptylaniline concentration having slopes 0.68 and 0.97 respectively (Figure 3). Similarly, the graph of $\log \mathrm{D}_{[\mathrm{Zn}(\mathrm{III}]}$ versus Log $\mathrm{C}_{\text {[N-n-heptylaniline] }}$ at $2.0 \mathrm{M}$ and $6.0 \mathrm{M} \mathrm{HCl}$ concentration having the slopes of 1.66 and 1.59 respectively (Figure 4). The stoichiometry of the extracted species is calculated to be 1:1:2 (metal: acid: extractant).

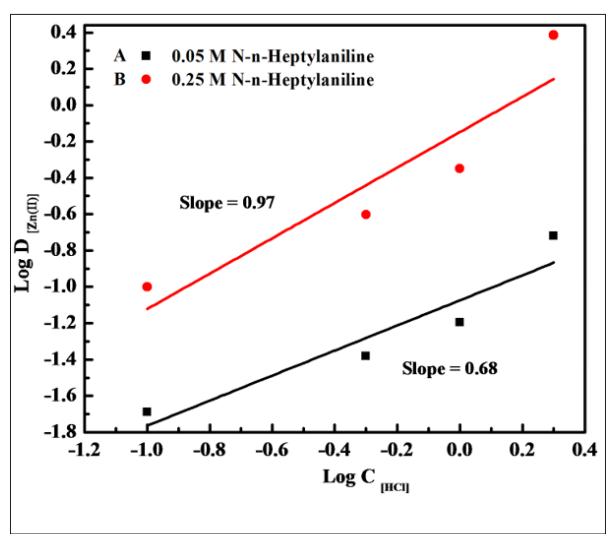

Figure 3: $\log -\mathrm{Log}$ plot of $\log \mathrm{D}[\mathrm{Zn}(\mathrm{II})]$ versus $\mathrm{Log} \mathrm{C}[\mathrm{HCl}]$ Condition: A) $0.05 \mathrm{M}$ N-n-heptylaniline, $\mathrm{Zn}(\mathrm{II})=1 \mathrm{mg}$, aq.: org. ratio $=1: 1$, shaking time $=1 \mathrm{~min}$, strippant $=$ ammonia buffer $(2 \times 10 \mathrm{~mL})$. B) $0.25 \mathrm{M} \mathrm{N}$-n-heptylaniline, $\mathrm{Zn}(\mathrm{II})=1 \mathrm{mg}$, aq.: org. ratio $=1: 1$, shaking time $=1 \mathrm{~min}$, strippant $=$ ammonia buffer $(2 \times 10 \mathrm{~mL})$.

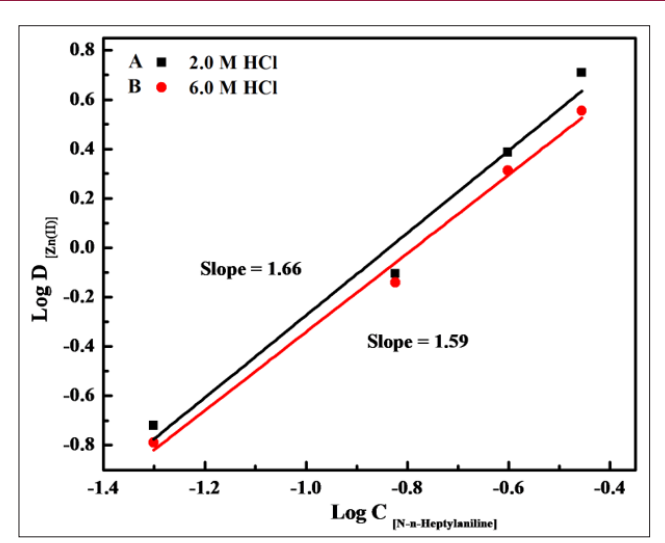

Figure 4: Log-Log plot of $\log \mathrm{D}[\mathrm{Zn}(\mathrm{II})]$ versus $\log \mathrm{C}[\mathrm{N}$ nHA] Condition: A) $2.0 \mathrm{M} \mathrm{HCl}, \mathrm{Zn}(\mathrm{II})=1 \mathrm{mg}$, N-nheptylaniline $=0.5 \mathrm{M}$ in xylene, aq.: org ratio : $1: 1$, shaking time $=1 \mathrm{~min}$, strippant $=$ ammonia buffer $(2 \times 10 \mathrm{~mL}) . \mathrm{B})$ 6.0 M HCl, Zn(II) $=1 \mathrm{mg}$, N-n-heptylaniline $=0.5 \mathrm{M}$ in xylene, aq.: org ratio : $1: 1$, shaking time $=1 \mathrm{~min}$, strippant $=$ ammonia buffer $(2 \times 10 \mathrm{~mL})$.

Hence the probable extracted species is: $\left[\left(\mathrm{RR}^{\prime} \mathrm{NH}_{2}{ }^{+}\right)_{2} \mathrm{ZnCl}_{4}{ }^{2-}\right]$ and the extraction mechanism appears to be,

$$
\begin{aligned}
& \mathrm{Zn}^{2+}+4 \mathrm{Cl}^{-}+\mathrm{HCl} \rightleftharpoons \mathrm{ZnCl}_{4}{ }^{2-} \\
& {\left[\mathrm{RR}^{\prime} \mathrm{NH}\right]_{\mathrm{org}}+\mathrm{HCl} \rightleftharpoons\left[\mathrm{RR}^{\prime} \mathrm{NH}_{2}+\mathrm{Cl}^{-}\right]}
\end{aligned}
$$

$2\left[\mathrm{RR}^{\prime} \mathrm{NH}_{2}+\mathrm{Cl}^{-}\right]_{\text {org }}+\mathrm{ZnCl}_{4}{ }^{2-} \rightleftharpoons\left[\left(\mathrm{RR}^{\prime} \mathrm{NH}_{2}^{+}\right)_{2} \mathrm{ZnCl}_{4}^{2-}\right]_{\text {org. }}+2 \mathrm{Cl}^{-}(3)$

Where, $\mathrm{R}=\mathrm{C}_{7} \mathrm{H}_{15}$ and $\mathrm{R}^{\prime}=\mathrm{C}_{6} \mathrm{H}_{5}$

\section{Applications}

\section{Influence of Foreign Ions}

A number of ions were tested for the interference in the extraction of zinc(II) and complexometric determination. Varying amounts of foreign ions were added to $1 \mathrm{mg}$ of zinc(II) (in $10 \mathrm{~mL}$ of solution) and recommended extraction procedure was followed. There was no interference from (as shown by less than $1.0 \%$ deviation of zinc(II) recovery) from $5 \mathrm{mg}$ each of manganese(II), silver(I), gold(III) and thallium(I), aluminium(III); $2.5 \mathrm{mg}$ each of calcium(II), beryllium(II), magnesium(II), chromium(VI); 100mg each of fluoride, acetate, thiocyanate; $60 \mathrm{mg}$ each of thiourea, ascorbate, $40 \mathrm{mg}$ each of thiosulphate, $10 \mathrm{mg}$ each of phosphate and malonate. Copper(II), nickel(II), cobalt(II), mercury(II), bismuth(III) and lead co-extract. Of which bismuth(III) and lead(II) were masked with thiourea. The results are tabulated in Table 4 .

Table 4: Effect of diverse ions.

\begin{tabular}{|c|c|c|}
\hline Foreign ion & Added as & Tolerance limit mg \\
\hline $\mathrm{Mn}(\mathrm{II})$ & $\mathrm{MnCl}_{2}$ & 05 \\
\hline $\mathrm{Ag}(\mathrm{I})$ & $\mathrm{AgNO}_{3}$ & 05 \\
\hline $\mathrm{Au}(\mathrm{III})$ & $\mathrm{AuCl}_{4} \cdot \mathrm{H}_{2} \mathrm{O}$ & 05 \\
\hline $\mathrm{Tl}(\mathrm{I})$ & $\mathrm{TlNO}_{3}$ & 05 \\
\hline $\mathrm{Th}(\mathrm{IV})$ & $\mathrm{Th}_{\left(\mathrm{NO}_{3}\right)_{2}}$ & 05 \\
\hline
\end{tabular}




\begin{tabular}{|c|c|c|}
\hline $\mathrm{Al}(\mathrm{III})$ & $\mathrm{AlCl}_{3} \cdot 6 \mathrm{H}_{2} \mathrm{O}$ & 05 \\
\hline $\mathrm{Bi}(\mathrm{III})^{\mathrm{a}}$ & $\mathrm{Bi}\left(\mathrm{NO}_{3}\right)_{3} \cdot 3 \mathrm{H}_{2} \mathrm{O}$ & 05 \\
\hline $\mathrm{Pb}(\mathrm{II})^{\mathrm{a}}$ & $\mathrm{Pb}\left(\mathrm{NO}_{3}\right)_{2}$ & 05 \\
\hline $\mathrm{Ca}(\mathrm{II})$ & $\mathrm{CaCl}_{2}$ & 2.5 \\
\hline $\mathrm{Ba}(\mathrm{II})$ & $\mathrm{BaCl}_{2}$ & 2.5 \\
\hline $\operatorname{Mg}(\mathrm{II})$ & $\mathrm{MgCl}_{2}$ & 2.5 \\
\hline $\mathrm{Cr}(\mathrm{VI})$ & $\mathrm{K}_{2} \mathrm{Cr}_{2} \mathrm{O}_{7}$ & 2.5 \\
\hline $\operatorname{In}(\mathrm{III})$ & $\mathrm{InCl}_{3}$ & 1.0 \\
\hline $\mathrm{Cu}(\mathrm{II})$ & $\mathrm{CuSO}_{4} \cdot 5 \mathrm{H}_{2} \mathrm{O}$ & Co-extract \\
\hline $\mathrm{Ni}(\mathrm{II})$ & $\mathrm{NiCl}_{2} 6 \mathrm{H}_{2} \mathrm{O}$ & Co-extract \\
\hline $\mathrm{Co}(\mathrm{II})$ & $\mathrm{CoCl}_{2} \cdot 6 \mathrm{H}_{2} \mathrm{O}$ & Co-extract \\
\hline Fluoride & Sodium fluoride & 100 \\
\hline Tartrate & Tartaric acid & 10 \\
\hline Thiourea & Thiourea & 60 \\
\hline Ascorbate & Ascorbic acid & 60 \\
\hline Malonate & Malonic acid & 10 \\
\hline Citrate & Citric acid & Co-extract \\
\hline Oxalate & Oxalic acid & 100 \\
\hline Acetate & Sodium acetate & 100 \\
\hline Thiocyanate & KSCN & 100 \\
\hline
\end{tabular}

\begin{tabular}{|c|l|l|}
\hline $\left.\mathrm{Bi}_{(\mathrm{III}}\right)^{\mathrm{a}}$ & 1 & 99.9 \\
\hline $\mathrm{Zn}(\mathrm{II})$ & 1 & 99.7 \\
\hline $\mathrm{Pb}(\mathrm{II})^{\mathrm{a}}$ & 1 & 99.8 \\
\hline
\end{tabular}

Note: ${ }^{\mathrm{a}}=$ Masked with thiourea

\section{Separation of Zinc(II) from Synthetic Mixtures}

Synthetic mixtures containing chromium(VI), gold(III), silver(I) in addition to zinc(II) are analyzed by the proposed method. zinc(II) from organic phase is back stripped with $0.5 \mathrm{M}$ ammonia and is determined complexometrically. The results given in Table 6 show that the separation of zinc(II) is possible from synthetic multicomponent mixtures.

Table 6: Separation of zinc(II) from synthetic mixtures.

\begin{tabular}{|c|c|c|}
\hline $\begin{array}{c}\text { Composition of the mixture } \\
\text { (mg) }\end{array}$ & Zinc(II) found, (mg) & \% Recovery \\
\hline $\mathrm{Zn}(\mathrm{II}), 1 ; \mathrm{Cr}(\mathrm{VI}), 1 ; \mathrm{Mo}(\mathrm{VI}), 1$ & 0.998 & 99.9 \\
\hline $\mathrm{Zn}(\mathrm{II}), 1 ; \mathrm{Au}(\mathrm{III}), 1 ; \mathrm{Ag}(\mathrm{I}), 1$ & 0.996 & 99.8 \\
\hline $\mathrm{Zn}(\mathrm{II}), 1 ; \mathrm{Mg}(\mathrm{II}), 1 ; \mathrm{In}(\mathrm{III}), 1$ & 0.998 & 99.9 \\
\hline $\mathrm{Zn}(\mathrm{II}), 1 ; \mathrm{Ca}(\mathrm{II}), 1 ; \mathrm{Th}(\mathrm{IV}), 1$ & 0.997 & 99.8 \\
\hline $\mathrm{Zn}(\mathrm{II}), 1 ; \mathrm{Mn}(\mathrm{II}), 1 ; \mathrm{In}(\mathrm{III}), 1$ & 0.997 & 99.8 \\
\hline
\end{tabular}

\section{Analysis of 'Nycil' Talcum Powder}

To $0.5 \mathrm{~g}$ of sample placed in a flask add $2 \mathrm{~mL}$ of conc. nitric acid and $10 \mathrm{~mL} 3 \% \mathrm{KMnO}_{4}$. The mixture is heated on water-bath for $30 \mathrm{~min}$ at $70-80^{\circ} \mathrm{C}$. Excess permanganate was removed by adding solid oxalic acid. The solution was diluted to $100 \mathrm{~mL}$ and extract zinc(II) as described in extraction procedure. The results of analysis are reported in Table 7.

Table 7: Analysis of commercial sample.

In order to establish the validity of the proposed extraction procedure, the method has been applied for the separation of zinc(II) from binary mixture. The binary separation of each metal ion was achieved by selective extraction of zinc(II) leaving behind other metals in raffinate. The method was applied for the separation of Al(III), In(III), Th(IV), Tl(I), Bi(III) and Pb(II) Table 5. The extracted zinc(II) from loaded N-n-heptylaniline was stripped by washing the organic phase using $0.5 \mathrm{M}$ ammonia.

Table 5: Separation of zinc(II) from binary mixtures.

\begin{tabular}{|c|c|c|}
\hline Metal ion & Concentration, $\mathbf{~ g ~}$ & Average \% Recovery* \\
\hline $\mathrm{Zn}(\mathrm{II})$ & 1 & 99.8 \\
\hline $\mathrm{Al}(\mathrm{III})$ & 1 & 99.7 \\
\hline $\mathrm{Zn}(\mathrm{II})$ & 1 & 99.9 \\
\hline $\mathrm{In}(\mathrm{III})$ & 1 & 99.7 \\
\hline $\mathrm{Zn}(\mathrm{II})$ & 1 & 99.8 \\
\hline $\mathrm{Th}(\mathrm{IV})$ & 1 & 99.8 \\
\hline $\mathrm{Zn}(\mathrm{II})$ & 1 & 99.9 \\
\hline $\mathrm{Tl}(\mathrm{I})$ & 1 & 99.8 \\
\hline $\mathrm{Zn}(\mathrm{II})$ & 1 & 99.9 \\
\hline
\end{tabular}

\begin{tabular}{|c|c|c|c|c|}
\hline Sample & Manufacturer & Composition & $\begin{array}{l}\text { Nominal } \\
\text { amount of } \\
\text { metal (\%) }\end{array}$ & $\begin{array}{c}\text { Result } \\
\text { found } \\
(\%)\end{array}$ \\
\hline $\begin{array}{l}\text { "Nycil” } \\
\text { (Prickly } \\
\text { heat } \\
\text { powder) }\end{array}$ & $\begin{array}{c}\text { Glaxo } \\
\text { Laboratories } \\
\text { (India) Ltd. }\end{array}$ & $\begin{array}{c}\text { Chlorphenesin } \\
\text { BP, } 1 \% \text {, } \\
\text { Boric acid IP } \\
5 \% \text {; } \\
\text { Zinc(II) oxide IP } \\
16 \% \text {; } \\
\text { Starch IP } 51 \%\end{array}$ & 12.85 & $\begin{array}{l}12.16- \\
12.29 \\
(\text { Mean } \\
12.24)\end{array}$ \\
\hline
\end{tabular}

Note: *Average of six determinations.

\section{Analysis of Zinc(II) from Pharmaceutical Samples}

A tablet was dissolved in concentrated perchloric acid and solution was evaporated to near dryness. The residue was taken up in the minimum amount of perchloric acid and solution was evaporated to dryness again. The residue was then leached with water and diluted to $100 \mathrm{~mL}$ with water. An aliquot was taken for the extraction and estimation of zinc(II) by the recommended procedure. The mean of six results is reported in Table 8. 
Table 8: Analysis of pharmaceutical samples

\begin{tabular}{|c|c|c|c|c|}
\hline Sample & Manufacturer & Composition & Amount of Zinc(II) certified & $\begin{array}{c}\text { Amount Found (Proposed } \\
\text { Method) }\end{array}$ \\
\hline Levozen-Z & $\begin{array}{c}\text { Alembic Formulation Pvt. Ltd, } \\
\text { Roper Road, Nalagarh }\end{array}$ & $\begin{array}{c}\text { Zinc(II) sulphate } \\
\text { monohydrate 61.8mg }\end{array}$ & $22.5 \mathrm{mg}$ & $22.3 \mathrm{mg}$ \\
\hline Folinz & $\begin{array}{c}\text { Apex Labs Pvt. Ltd., B-23, } \\
\text { Sidco Pharmaceutical complex, } \\
\text { Latur-603110 }\end{array}$ & $\begin{array}{c}\text { Zinc(II) sulphate } \\
\text { monohydrate 55mg }\end{array}$ & $20.03 \mathrm{mg}$ & $19.7 \mathrm{mg}$ \\
\hline
\end{tabular}

Note: *Average of six determinations

Conditions: $\mathrm{Zn}(\mathrm{II})=1 \mathrm{mg}$, N-n-heptylaniline $=0.5 \mathrm{M}, \mathrm{HCl}=3.0 \mathrm{M}$, aq.: org. ratio $=1: 1$, Shaking time $=1 \mathrm{~min}$, strippant $=$ ammonia buffer $(2 \times 10 \mathrm{~mL})$.

\section{Conclusion}

The present investigation highlights that N-n-heptylaniline is very effective ion-pair forming extractant. The method can be applied for simultaneous determination of zinc(II) in synthetic mixtures, commercial sample and pharmaceutical sample. The stoichiometry of the proposed method was found to be 1:1:2 (metal: extractant: acid).

\section{References}

1. Welz B, Sperling M (1999) Atomic Absorption spectrometry, ( $3^{\text {rd }}$ edn). John Wiley \& Sons, p.965.

2. Mulik GN, Kuchekar SR, Chavan MB (1986) Solvent extraction of zinc(II), indium(III), thallium(III) and bismuth(III) with n-octylaniline from hydrochloric acid media and their separation. Ind J Chem 25: 1073-1074.

3. Patkar SN, Patil SD, Patil RJ (2012) Liquid-liquid extraction and separation of zinc(II) with synergistic mixture of n-n-octylaniline and trioctylamine as an extractant. IOSR-JAC 2: 18-25.

4. Kadam Patil NB, Thorat RB, Burungale AS (2009) Liquid-liquid extraction and separation of zinc(II) with N-n-hexylaniline. Rasayan J Chem 2(4): 953-959.

5. Lee MS, Nam SH (2009) Solvent extraction of zinc from strong hydrochloric acid solution with Alamine336. Bull Korean Chem Soc 30: 1526-1530.

6. Senhaji SB, Elyahyaoui A (2015) Liquid-liquid extraction of zinc by 3-mehyl-quinoxaline -2-thione from nitrate medium. Oriental J Chem 31(3): 1601-1609.

7. Patnaik P, Baba AA, Nathsarma KC, Sarangi K, Subbaiah T (2013) Separation of iron and zinc from manganese nodule leach liquor using TBP as an extractant. Trans Inst Min Metall 122: 179-185.

8. Balesini AA, Razavizadeh H, Zakeri A(2011) Solvent extraction of zinc from acidic solution obtained from cold purification filter cake of Angouran mine concentrate using $\mathrm{D}_{2}$ EHPA. Iranian J of chem Engineering 8: $43-47$.

9. Lum KH, Stevens GW, Perera JM, Kentish SE (2013) The Modelling of $\mathrm{ZnCl}_{2}$ extraction and $\mathrm{HCl}$ co-extraction by TBP diluted in Shellsol 2046. Hydrmetallurgy 133: 64-74.

10. Jha MK, Kumar V, Singh RJ (2002) Solvent extraction of zinc from chloride solutions. Solv Ext and ion Exch 20: 389-405.

11. Madrakian T, Moein R, Bahram M (2008) Simultaneous spectrophotometric determination of zinc and nickel in water samples by mean centering of ratio kinetic profiles. J Chin Chem Soc 55: 788-793.

12. Jia Q Li D, Niu C (2002) Synergistic extraction of zinc(II) by mixtures of primary amine N1923 and cyanex272. Solv Ext and ion Exch 20: 751764.
13. Mellah A, Benachour D (2007) The solvent extraction of zinc, cadmium and chromium from phosphoric acid solutions by tri- $n$-butyl phosphate in kerosene diluent. Sep and Purif Tech 56: 220-224.

14. Mishra RK, Rout PC, Sarangi K, Nathsarma KC (2016) Solvent extraction of zinc, manganese, cobalt and nickel from nickel laterite bacterial leach liquor sodium salts of TOPS-99 and cyanex-272. Trans Nonferrous Met Soc China 26: 301-309.

15. Mansur MB, Rocha SD, Magalhães FS, Benedetto Jdos S (2008) Selective extraction of zinc(II) over iron(II) from spent hydrochloric acid pickling effluents by liquid-liquid extraction. J Hazard Mater 150: 669-678.

16. Nathsarma KC, Bhaskara Sarma PVR (2003) Solvent extraction of cobalt and zinc from sulphate solutions using phosphoric, phosphonic and phosphinic acids. Europ J Min process Environ Prot 3: 151-159.

17. Pereira DD, Rocha SDF, Mansur MB (2007) Recovery of zinc sulphate from industrial effluents by liquid-liquid extraction using $\mathrm{D}_{2}$ EHPA (di-2ethylhexyl phosphoric acid). Sep and Purif Tech 53: 89-96.

18. Tian M, Mu F, Jia Q, Quan X, Liao W (2011) Solvent extraction studies of zinc(II) and cadmium(II) from a chloride medium with mixtures of neutral organophosphorus extractants and amine extractants. I Chem Eng Data 56: 2225-2229.

19. Pospiech B (2014) Synergistic solvent extraction and transport of Zn(II) and $\mathrm{Cu}$ (II) across polymer inclusion membranes with a mixture of TOPO and Aliquat 336. Sep Sci and Tech 49: 1706-1712.

20. Sayar NA, Filiz M, Sayar AA (2007) Extraction of Zn(II) from aqueous hydrochloric acid solutions into Alamine 336-m-xylene systems. Hydrometallurgy 86: 27-36.

21. Kiran K (2012) Spectrophotometric determination of zinc in water samples using 3-hydroxybenzylaminobenzoic acid. Chem Sci Trans 1(3): 669-673.

22. Agrawal A, Kumari S, Sahu KK (2008) Liquid-liquid extraction of sulphuric acid from zinc bleed stream. Hydrometallurgy 92: 42-47.

23. Dessouky SIE, El Nadi YA, Ahmed IM, Saad EA, Daoud JA (2008) Solvent extraction separation of $\mathrm{Zn}(\mathrm{II}), \mathrm{Fe}(\mathrm{II}), \mathrm{Fe}(\mathrm{III})$ and Cd(II) using tributylphosphate and Cyanex 921 in kerosene from chloride medium. Chem Engg Process 47: 177-183.

24. Kuchekar SR, Aher HR, Chavan MB (2003) Solvent extraction of zinc(II), cadmium(II), mercury(II) and bismuth(III) using n-octylaniline and their separations. Ind J chem 42: 1674-1676.

25. Tekale PP (2012) Extractive spectroscopic estimation of zinc from food and pharmaceutical samples using 1-phenyl-1-hydrazonyl-2-oximino propane-1, 1-dione reagent. Der Pharmacia Lettre 4: 1883-1887.

26. Pawar RR, Suryavanshi VJ, Salunkhe ST, Patil SS, Mulik GN (2016) Liquidliquid extraction of thorium(IV) with N-n-heptylaniline from acid media. J Radioanal Nucl Chem 311(1): 419-426.

27. Khogare BT, Kamble GS, Kokare AN, Zanje SB, Suryavanshi VJ, et al. (2016) Development of novel solvent extraction method for determination

Cite this article: Pawar RR, Suryavanshi VJ, Patil MM, Patil SS, Mulik GN. Liquid- Liquid Extraction of Zinc(II) From Acid Media with N-nHeptylaniline as an Extractant: Analysis of Pharmaceutical and Commercial Sample. Biomed J Sci\&Tech Res 10(3)-2018. BJSTR. MS.ID.001965. 
of gold(III) using 4-heptylaminopyridine: Application to alloys and environmental analysis. J Environ Chem Engg 4: 3075-3083.

28. Kokare A, Suryavanshi V, Zanje S, Kore G, Anuse M (2016) Liquid-liquid extraction and separation of lead(II) by using N-n-octylcyclohexylamine as an extractant: Analysis of real samples. Anal Methods 8: 6158-6167.

29. Zanje SB, Kokare AN, Suryavanshi VJ, Kore GD, Khogare BT, et al. (2016) Extractive spectrophotometric determination of platinum in cisplatin injection, alloys and catalysts assisted by 2-nitrobenzaldehydethiocarbohrdrazone. J Trace Analysis Food Drug 2: $1-24$.

30. Suryavanshi VJ, Pawar RR, Anuse MA, Mulik GN (2015) 2-Octylaminopyridine assisted solvent extraction system for selective separation of palladium(II) ion-pair complex from synthetic mixtures and real samples. Anal Methods 7: 2497-2504.

31. Suryavanshi VI, Patil MM, Zanje SB, Kokare AN, Kore GD, et al (2016) Extraction of iridium(III) by ion-pair formation with 2-octylaminopyridine in weak organic acid media. Sep Sci Technol 51: 1690-1699.

32. Suryavanshi VJ, Patil MM, Kokare AN, Zanje SB, Pawar RR, et al. (2016) Development of a liquid-liquid extraction system for Rhodium(III) by 2-octylaminopyridine from weak malonate media. J Chin Chem Soc 63: 694-702.

33. Zanje SB, Kokare AN, Suryavanshi VJ, Waghmode DP, Joshi SS, et al. (2016) Development of a reliable analytical method for the precise extractive spectrophotometric determination of Osmium(VIII) with 2-nitrobenzaldehydethiocarbohydrazone: Analysis of alloys and real sample. Spectrochim Acta A Mol Biomol Spectrosc 169: 223-229.

34. Gaikwad AP, Suryavanshi VJ, Anuse MA (2017) Solvent extraction studies of Rhodium(III) by using n-octylaniline from malonate media: Analysis of synthetic mixtures and alloys. Cogent Chemistry Vol 3.

\section{ISSN: 2574-1241}

DOI: $10.26717 / B J S T R .2018 .10 .001965$

Mulik GN. Biomed J Sci \& Tech Res

(c) (i) This work is licensed under Creative BY Commons Attribution 4.0 License

Submission Link: https://biomedres.us/submit-manuscript.php
35. Suryavanshi VJ, Patil MM, Zanje SB, Kokare AN, Gaikwad AP, et al. (2017) Development of liquid-liquid extraction and separation method for Ruthenium(III) with 2-octylaminopyridine from succinate media: analysis of catalysts. Russian J Inorg Chem 62: 257-268.

36. Suryavanshi VJ, Kokare AN, Zanje SB, Mulik AG, Patil MM, et al. (2018) Ion-pair based liquid-liquid extraction of gold(III) from malonate media using 2-octylaminopyridine as an extractant: Analysis of alloys, minerals, and drug samples. Turk J Chem 42: 1032-1044.

37. Kokare A, Suryavanshi V, Zanje S, Kore G, Waghmode D, et al. (2017) Development of a rapid and reliable liquid-liquid extractive method for the effective removal of Chromium(VI) from electroplating waste water and tannery effluents. Russian J Inorg Chem 62: 527-538.

38. Gaikwad AP, Suryavanshi VJ, Anuse MA (2017) Liquid-liquid extraction studies of Ruthenium(III) from malonate medium using n-octylaniline as an ion-pairing reagent: Study of catalyst and alloys. Bulg Chem Comm 49: 914-922.

39. Zanje SB, Suryavanshi VI, Kokare AN, Ghare AA, Kamble GS, et al. (2018) 2-nitrobenzaldehyde Thiocarbohydrazone assisted precise extraction spectrophotometric method for the determination of Ruthenium(III) in alloy and catalysts. J Anal Chem 73: 438-451.

40. Gardlund ZG, Curtis RJ, Smith GW (1973) Influence of molecular structural changes on the mesomorphic behaviour of benzylideneanilines. Liquid crystals and ordered fluids 2: 541-556.

41. Vogel AI (1975) A text book of quantitative inorganic analysis, ( $3^{\text {rd }}$ edn). Longmans, London, p 541.

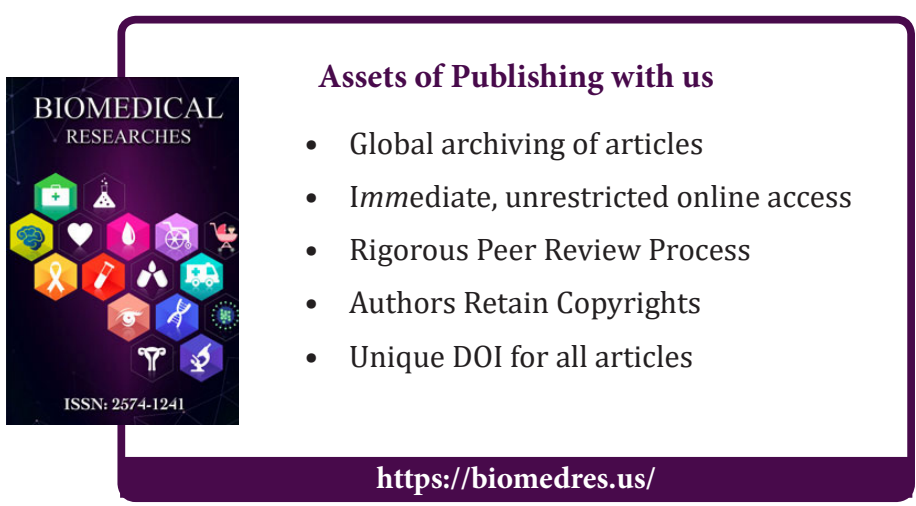

Cite this article: Pawar RR, Suryavanshi VJ, Patil MM, Patil SS, Mulik GN. Liquid- Liquid Extraction of Zinc(II) From Acid Media with N-nHeptylaniline as an Extractant: Analysis of Pharmaceutical and Commercial Sample. Biomed J Sci\&Tech Res 10(3)-2018. BJSTR. MS.ID.001965. 